\title{
Antibody-based techniques for detection of Lyme disease: a challenging issue
}

This article was published in the following Dove Press journal:

Antibody Technology Journal

30 July 2014

Number of times this article has been viewed

\section{Joanna M Zajkowska}

Department of Infectious Diseases and Neuroinfections, Medical University in Białystok, Białystok, Poland
Correspondence: Joanna M Zajkowska Department of Infectious Diseases and Neuroinfections, Medical University in Białystok, Jana Kilińskiego I, Białystok, Poland

Email zajkowsk@umb.edu.pl
Abstract: Serologic assays detecting antibodies to Borrelia burgdorferi are useful in the routine diagnosis of Lyme disease. Despite the presence of new and improved assays, current laboratory diagnosis still requires optimization. The variety of genospecies and their different geographic distributions are the reasons why standards and recommendations are not the same for all of the main geographic regions, ie, USA, Asia, and Europe. Moreover, the variety and variability of antigens represents a significant challenge in assay design. This is due to the various antigens among the genospecies responsible for Lyme borreliosis; the changing antigens presented during infection; and the variability of single antigens. This review article discusses the immunologic response in Lyme disease over time, and the advantages and disadvantages of existing serological tests. Two tier testing is also introduced. Antigens useful for diagnosis, the properties of individual antigens and their appearance in infection - especially the antigens appearing during mammalian infection, so-called "in vivo" antigens are introduced. To determine antibodies confirming infection in the nervous system, the same restrictions with regard to interpretation of enzyme-linked immunosorbent assay results in serum apply to cerebrospinal fluid. Furthermore, concentrations of antibodies in the two compartments, ie, blood and cerebrospinal fluid, are variable depending on compartmentalization (anatomic sequestration) and immunologic phenomena at immunologically privileged sites, such as the intrathecal space. To confirm neuroborreliosis, synthesis of antibodies in cerebrospinal fluid, should be measured in the form of a so-called antibody index. Further studies should focus on detecting the lowest concentration of antibodies and looking for useful new antigens, and the relationship between composition of such antigens and the patient's clinical status.

Keywords: Lyme borreliosis, antigens, serologic techniques, antibodies detection, immunological response, antibody index, neuroborreliosis

\section{Introduction}

Lyme disease is a tickborne bacterial infection transmitted to humans by the genus Ixodes. Unlike in North America, where Borrelia burgdorferi sensu stricto is mainly found, in Europe and Asia at least five pathogenic (of several) genospecies of Borrelia bacteria belonging to the B. burgdorferi sensu lato complex, for which the clinical picture is more varied, are responsible for Lyme disease. ${ }^{1-3}$

Primarily, B. burgdorferi sensu stricto, Borrelia afzelii, and Borrelia garinii, and according to some reports, Borrelia valaisiana, Borrelia lusitaniae, Borrelia spielmanii, and Borrelia bissetti, are among the complex bacteria B. burgdorferi sensu lato that cause Lyme borreliosis. Clinical descriptions of various forms of Lyme disease have been known in Europe for almost 100 years, but it was only 30 years ago in the USA that Willy Burgdorfer identified the bacterium B. burgdorferi. ${ }^{1,2}$ 
Table I Summary of clinical case definitions for Lyme borreliosis

\begin{tabular}{|c|c|c|c|}
\hline Term & Clinical case definition & $\begin{array}{l}\text { Laboratory evidence: } \\
\text { essential }\end{array}$ & Laboratory/clinical evidence: supporting \\
\hline $\begin{array}{l}\text { Erythema } \\
\text { migrans }\end{array}$ & $\begin{array}{l}\text { Expanding red or bluish-red patch ( } \geq 5 \mathrm{~cm} \\
\text { in diameter) }{ }^{\mathrm{a}} \text { with or without central clearing. } \\
\text { Advancing edge typically distinct, often } \\
\text { intensely colored, but not markedly elevated. }\end{array}$ & None & $\begin{array}{l}\text { Detection of Borrelia burgdorferi sensu lato by } \\
\text { culture and/or PCR from skin biopsy. }\end{array}$ \\
\hline $\begin{array}{l}\text { Borrelial } \\
\text { lymphocytoma } \\
\text { (rare) }\end{array}$ & $\begin{array}{l}\text { Painless bluish-red nodule or plaque, } \\
\text { usually on ear lobe, ear helix, nipple, } \\
\text { or scrotum; more frequent in children } \\
\text { (especially on the ear) than in adults. }\end{array}$ & $\begin{array}{l}\text { Seroconversion or } \\
\text { positive serology } \\
\text { Histology in unclear } \\
\text { cases }\end{array}$ & $\begin{array}{l}\text { Histology. Detection of B. burgdorferi sensu lato by } \\
\text { culture and/or PCR from skin biopsy. Recent or } \\
\text { concomitant erythema migrans. }\end{array}$ \\
\hline $\begin{array}{l}\text { Acrodermatitis } \\
\text { chronica } \\
\text { atrophicans }\end{array}$ & $\begin{array}{l}\text { Longstanding red or bluish-red lesions, usually } \\
\text { on the extensor surfaces of extremities. Initial } \\
\text { doughy swelling. Lesions eventually become } \\
\text { atrophic. Possible skin induration and fibroid } \\
\text { nodules over bony prominences. }\end{array}$ & $\begin{array}{l}\text { High level of specific } \\
\text { serum lgG antibodies }\end{array}$ & $\begin{array}{l}\text { Histology. Detection of B. burgdorferi sensu lato by } \\
\text { culture and/or PCR from skin biopsy. }\end{array}$ \\
\hline $\begin{array}{l}\text { Lyme } \\
\text { neuroborreliosis }\end{array}$ & $\begin{array}{l}\text { In adults, mainly meningoradiculitis, } \\
\text { meningitis; rarely encephalitis, myelitis; } \\
\text { very rarely cerebral vasculitis. In children, } \\
\text { mainly meningitis and facial palsy. }\end{array}$ & $\begin{array}{l}\text { Pleocytosis and } \\
\text { demonstration of } \\
\text { intrathecal-specific } \\
\text { antibody synthesisc }\end{array}$ & $\begin{array}{l}\text { Detection of B. burgdorferi sensu lato by culture } \\
\text { and/or PCR from CSF. Intrathecal synthesis of total } \\
\text { IgM, IgG, and/or IgA. Specific serum antibodies. } \\
\text { Recent or concomitant erythema migrans. }\end{array}$ \\
\hline Lyme arthritis & $\begin{array}{l}\text { Recurrent attacks or persisent objective } \\
\text { joint swelling in one or a few large joints. } \\
\text { Alternative explanations must be excluded. }\end{array}$ & $\begin{array}{l}\text { Specific serum IgG } \\
\text { antibodies, usually in } \\
\text { high concentrations }\end{array}$ & $\begin{array}{l}\text { Synovial fluid analysis. Detection of B. burgdorferi } \\
\text { sensu lato by PCR and/or culture from synovial } \\
\text { fluid and/or tissue. }\end{array}$ \\
\hline $\begin{array}{l}\text { Lyme } \\
\text { carditis (rare) }\end{array}$ & $\begin{array}{l}\text { Acute onset of atrioventricular (I-III) } \\
\text { conduction disturbances, rhythm disturbances, } \\
\text { sometimes myocarditis or pancarditis. } \\
\text { Alternative explanations must be excluded. }\end{array}$ & $\begin{array}{l}\text { Specific serum } \\
\text { antibodies }\end{array}$ & $\begin{array}{l}\text { Detection of } B \text {. burgdorferi sensu lato by culture } \\
\text { and/or PCR from endomyocardial biopsy. } \\
\text { Recent or concomitant erythema migrans and/or } \\
\text { neurologic disorders. }\end{array}$ \\
\hline $\begin{array}{l}\text { Ocular } \\
\text { manifestations } \\
\text { (rare) }\end{array}$ & $\begin{array}{l}\text { Conjunctivitis, uveitis, papillitis, } \\
\text { episcleritis, keratitis. }\end{array}$ & $\begin{array}{l}\text { Specific serum } \\
\text { antibodies }\end{array}$ & $\begin{array}{l}\text { Recent or concomitant Lyme borreliosis } \\
\text { manifestations. Detection of B. burgdorferi sensu } \\
\text { lato by culture and/or PCR from ocular fluid. }\end{array}$ \\
\hline
\end{tabular}

Notes: alf $<5 \mathrm{~cm}$ in diameter, a history of tick bite, a delay in appearance (after the tick bite) of at least 2 days, and an expanding rash at the site of the tick bite is required; bas a rule, initial and follow-up samples have to be tested in parallel in order to avoid changes because of interassay variation; in early cases, intrathecally produced specific antibodies may still be absent. Reproduced with permission from Lyme borreliosis: Clinical case definitions for diagnosis and management in Europe, Stanek G, Fingerle V, Hunfeld KP, et al, Clinical Microbiology and Infection, 17(1). Copyright (C) 2010 The Authors. Journal Compilation (C) 2010 European Society of Clinical Microbiology and Infectious Diseases. ${ }^{3}$

Abbreviations: PCR, polymerase chain reaction; Ig, immunoglobulin; CSF, cerebrospinal fluid.

During the three decades since the responsible spirochete was identified, a series of misconceptions and misunderstandings have become widespread, leading to frequent misdiagnosis and inappropriate treatment. Persistent misconceptions concern the reliability of available diagnostic tools, signs and symptoms of nervous system involvement, appropriate choice and duration of antimicrobial therapy, curability of the infection, and the cause of symptoms that may persist in some patients after treatment. ${ }^{3,4}$ Significant improvement in direct and indirect methods for diagnosis of Lyme disease has permitted clinical case definitions to be specified (Table 1). ${ }^{3}$

Laboratory diagnosis of Lyme disease is still a huge challenge, despite the constant development and improvement of testing. This is due to many factors, including various antigens among the genospecies responsible for Lyme borreliosis, the changing antigens presented during infection, and the variability of the single antigens. In addition, clinical interpretation of the immune response, lack of standardization of existing tests, and lack of a test for disease activity pose a significant problem. ${ }^{5,6}$

Only a few bites by infected ticks cause symptoms. The majority of infections are asymptomatic and eliminated by host defense mechanisms, but leave a trail of antibodies.

The diagnosis of Lyme disease involves a combination of clinical detection confirmed by laboratory tests. The gold standard in microbiology is direct detection of bacteria, but serologic tests can confirm infection indirectly. ${ }^{7,8}$ Serologic assays detecting antibodies to $B$. burgdorferi have become the most useful in routine diagnosis. ${ }^{8}$

An immunologic response in Lyme disease undergoes evolution. A measurable antibody response requires several weeks to develop (at least 2 weeks, depending on the sensitivity of the assay), often persists after successful treatment, and is not prevented by noncurative therapy. Seronegative early Lyme disease is uncommon, but there is no sufficient evidence of seronegative late Lyme disease. ${ }^{9}$ 


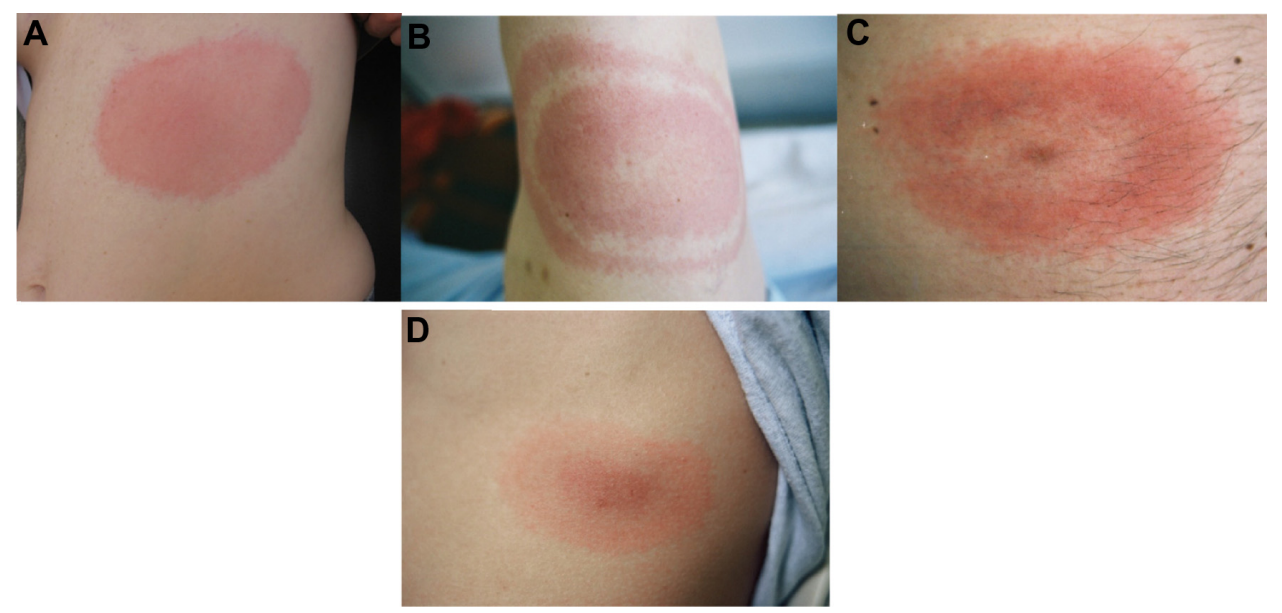

Figure I Typical expanding skin lesions.

Notes: Erythema migrans are essential for early diagnosis of B. burgdorferi. (A) homogenic type; (B) and (D) bulls eye type; (C) with central clearing.

There are many diagnostic tests for Lyme disease on the market. These tests are continually being improved, but innovations are protected by patent and warranted by companies, which makes standardizing and comparing them difficult. ${ }^{10-14}$ The pattern of immune response over time is not precise. Therefore, for recognition of Lyme disease caused by B. burgdorferi sensu lato, it is necessary to know not only the symptoms of the disease, but also the diagnostic parameters for laboratory tests and their limitations. Laboratory confirmation is not required, except in the form of early Lyme disease, ie, erythema migrans (Figure 1).

\section{Indirect tests}

The presence of antibodies is the result of an adaptive immunologic response based on antigen presentation. Serologic testing is performed to detect antibodies to B. burgdorferi antigens separately for a single antigen or a bundle of antigens. The antigen-antibody complex is measured depending on the method used, eg, chemiluminescence assay or radioimmunoassay. The result is reported in numerical values.

The enzyme-linked immunosorbent assay (ELISA) and indirect immunofluorescence assay have become the most commonly used techniques for the serodiagnosis of Lyme borreliosis, and are based on detection of antibodies against several B. burgdorferi antigens. ${ }^{8,10,15,16}$ The serum sample with antibodies is sandwiched between the antigens coated on the plate and an enzyme-labeled, antispecies globulin conjugate. The addition of an enzyme substrate-chromogen reagent causes color to develop. The advantages of ELISA are the small amount of sample and microwell plates needed and its high sensitivity.
The rules of interpretation for these techniques (including every assay) are determined by the manufacturer in order to classify samples as negative, equivocal, or positive using any given product. ${ }^{17,18}$ ELISA is one of the most widely used in biomedical research for both scientific and diagnostic purposes. ${ }^{19,20}$ Unfortunately, ELISAs cannot be used to monitor the success of treatment. Once elicited, antibodies remain elevated for several months or even years after elimination of the bacteria. ${ }^{21,22}$ This often results in misdiagnosis and unnecessary antibiotic prescribing. However, immunoserology is the most commonly used diagnostic method, and is recommended as a screening test. ${ }^{23-26}$

Immunoglobulin (Ig)M and IgG antibodies in the patient's serum bind specifically to the antigen-coated wells, resulting in color development. The intensity of color is equivalent to the level of antibodies.

ELISA tests can be qualitative, semiquantitative, or quantitative. As a preliminary test, the ELISA used is a mixture of antigens derived from one or more cultured pathogenic genospecies (native antigens) with synthesized (recombinant antigen) enrichment. The greater the sensitivity of the test, the larger the set (panel) of B. burgdorferi species and antigens. This type of test is by definition very sensitive, so over-reactivity has to be considered and positive results may be due to clinical conditions other than B. burgdorferi infection.

Standardization and reproducibility of testing is possible only in the context of a single product, given that companies use their own units. Many problems result from the fact that diagnostic tests for Lyme disease do not comprise the same panel of antigens. ${ }^{27,28}$ Due to the heterogeneity of genospecies and the nonuniform nature of these tests, there is a lack 


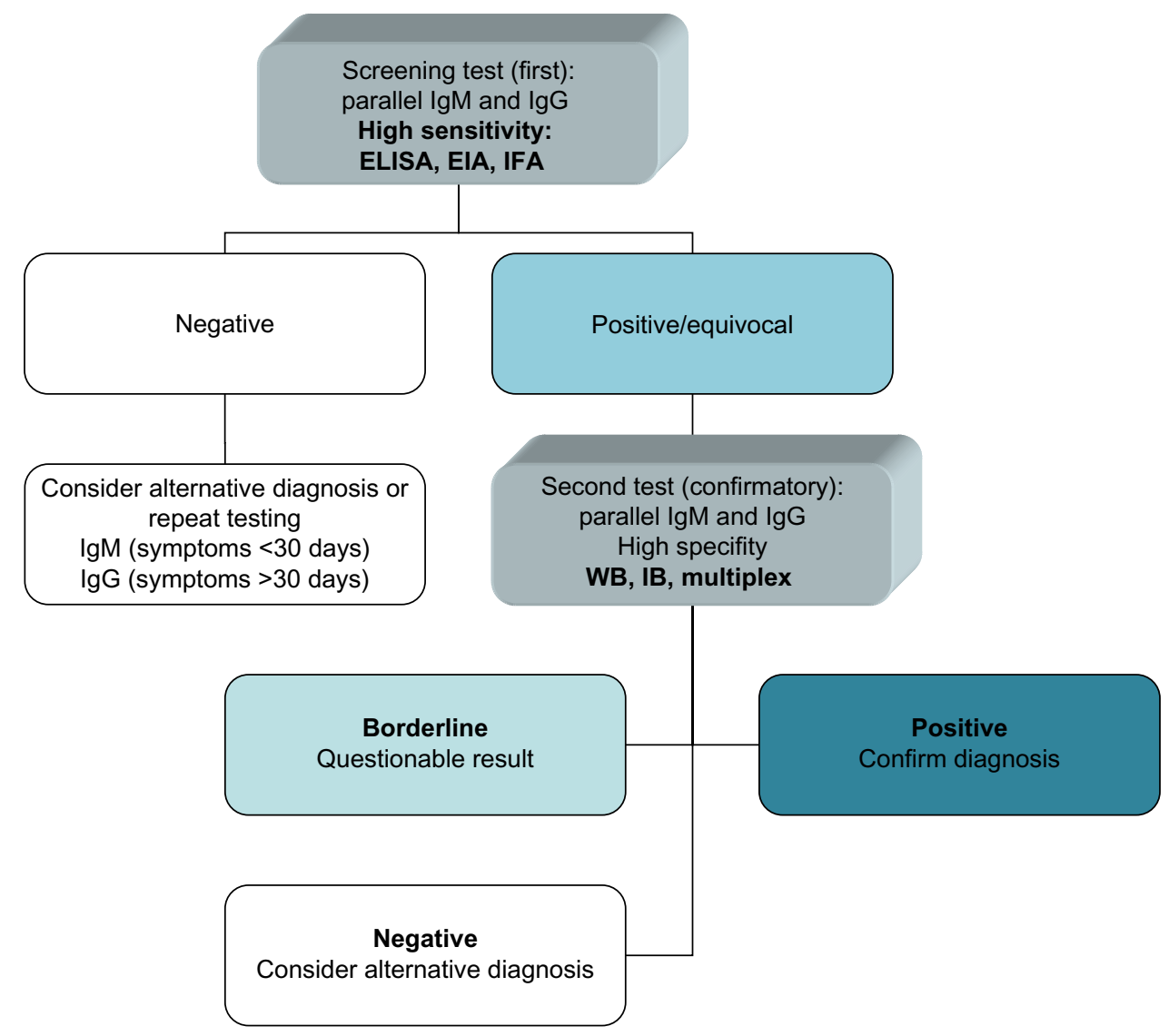

Figure 2 Two-tier testing.

Abbreviations: Ig, immunoglobulin; WB, Western blot; IB, immunoblot; ELISA, enzyme-linked immunosorbent assay; EIA, enzyme immunoassay; IFA, immunofluorescence assay.

of standardization (ie, similar but not uniform antigenic composition). The titers resulting from the tests are expressed in different units (eg, $\mathrm{U} / \mathrm{mL}, \mathrm{BBU} / \mathrm{mL}, \mathrm{AU} / \mathrm{mL})$ depending on the manufacturer. To be able to interpret serologic test results with a high level of sensitivity and specificity when seeking to make a diagnosis of Lyme borreliosis, it is necessary to take into consideration the seroprevalence in a given region. In a population with a low prevalence of the disease, tests will have a low positive predictive value, ie, the probability of indicating genuine disease will be lower. ${ }^{17}$ Antibodies are reported to be present in up to $12 \%$ of healthy individuals. ${ }^{18}$

ELISA is assumed to have high sensitivity but lower specificity, giving a result as a numeric value, adding up all of the antigen-antibody reactions detected by this test. Systems based on whole cell lysates, mostly derived from one genospecies, are limited by the antigen composition of the culture. Including several strains from different species enriched with recombinant antigens would increase the assay sensitivity. $23,24,27,28$

Further evaluation is required after obtaining a positive result by this method, and can be achieved using antibodies against the various antigens according to the Western blot, immunoblot, or multiplex. Strong antibody response against non specific antigen reported as numeric value (often falsepositive) is the same as response against some specific antigens (true-positive). The Western blot or immunoblot enables detection of antibodies against individual components of the organism and thus provides more information than a whole cell-based ELISA regarding which antigens of $B$. burgdorferi react with serum antibodies. Western blots can be performed to detect either IgM or IgG antibodies (Figure 2). In the Western blot assay, a mixture of bacterial antigens from one or more species enriched with recombinant antigens is subjected to electrophoretic separation which allows isolation of antibodies against individual antigens and arrangement according to their molecular weight. Electrophoresis of whole cell lysate made it possible to identify 30 separate protein bands, each with a different meaning, but only some of which are essential for a diagnosis of Lyme disease (Table 2).

The presence of antibodies against specific antigens is visible as bands. The result is assessed visually by comparison with a template field for identifying individual antibodies or 


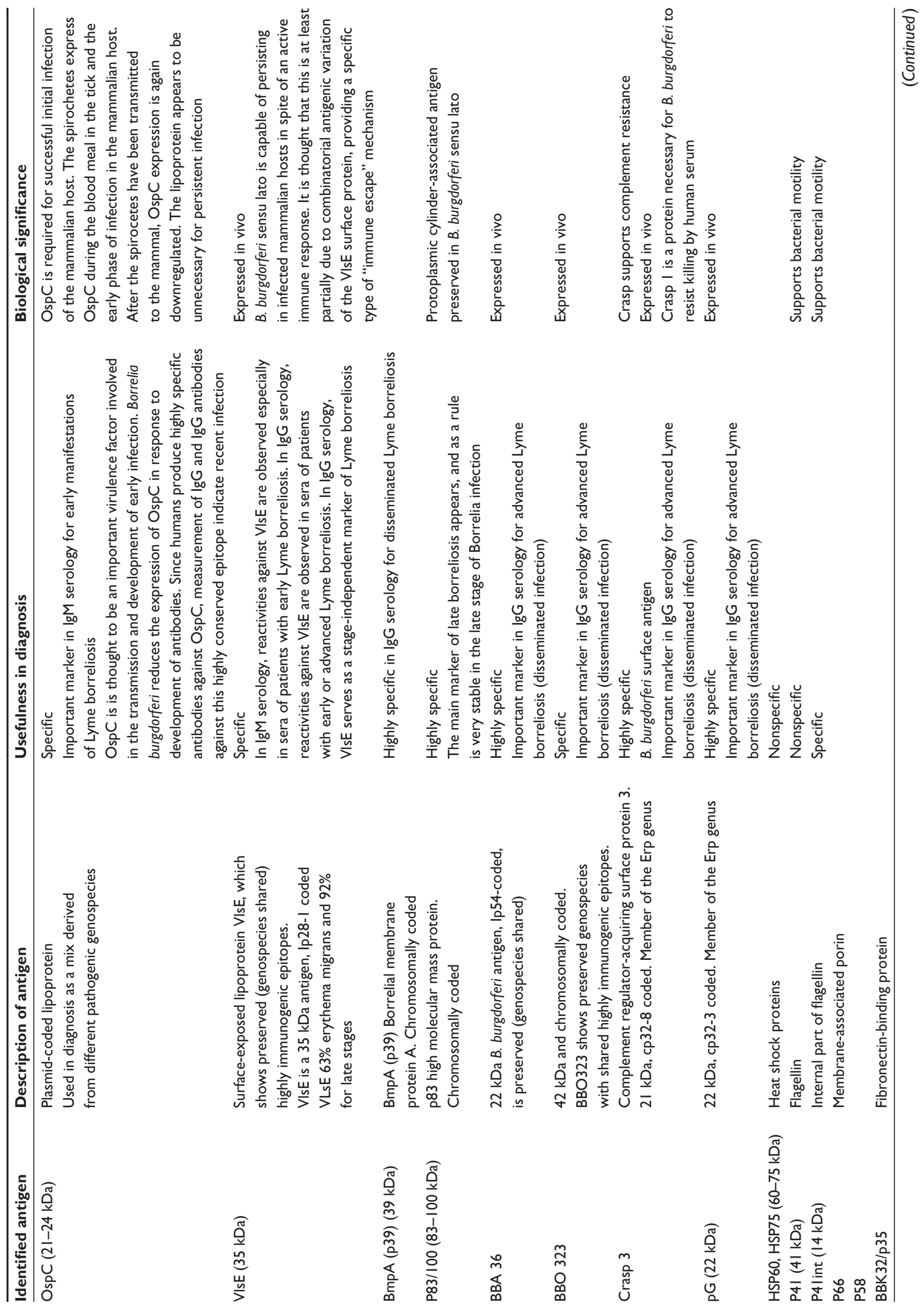




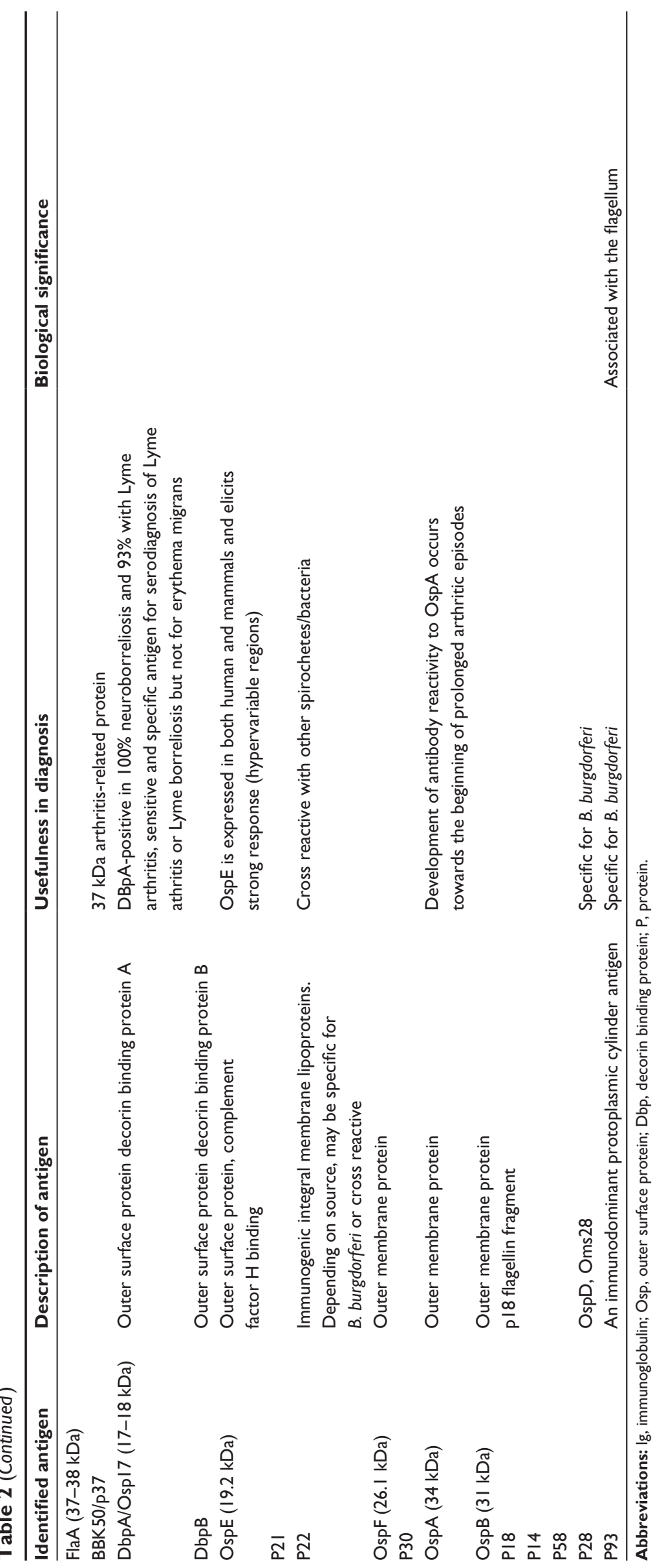


Table 3 US criteria for Western blot diagnosis of Lyme disease

\begin{tabular}{lll}
\hline Type of infection & Isotype & Bands to be considered \\
\hline First few weeks & IgM & Two of the following: OspC 24, 39, 4| \\
After first few & $\lg G$ & $\begin{array}{l}\text { Five of the following: I8, 23, 28, 30, } \\
\text { weeks }\end{array}$ \\
\hline
\end{tabular}

Note: Criteria for positive Western blot (immunoblot) analysis in the serologic confirmation of infection with Borrelia burgdorferi (Lyme disease). Data from Dressler et al. ${ }^{28}$

Abbreviation: Ig, immunoglobulin.

read by a scanner measuring the intensity of the single bands. However, these tests are not standardized either. Different distributions of pathogenic genospecies of B. burgdorferi in the USA, Europe, and Asia lead to difficulty when making recommendations. ${ }^{7,29,30}$ The information gleaned from studies correlating cases of clinically diagnosed Lyme disease with patterns of reactivity on Western blot have enabled the Centers for Disease Control and Prevention to recommend evidencebased criteria for Western blot interpretation (Table 3), which should be used to interpret results in the USA. ${ }^{28}$ However, interpretation criteria are different in Europe. ${ }^{31}$ In the USA, the guidelines refer to the whole cell antigen of B. burgdorferi sensu stricto, ie, the Dressler criteria. However, these rules are not universally applicable to immunoblots across Europe. , 24,30 $^{2,3}$ Interpretation criteria depend on the strain or species used as a source of antigen and it is necessary to characterize diagnostic antigens with monoclonal antibodies for appropriate identification of immunoblot bands. Standardization of criteria for interpretation of the immunoblot in Europe was the focus of a study by the European Concerted Action on Lyme Borreliosis group. ${ }^{24}$ Six European laboratories, using different immunoblot protocols, identified eight bands that were discriminatory in all laboratories, although with variations in significance. From these bands, five closely related European rules were formulated, giving acceptable sensitivity and specificity, although there was no single rule that could be applied in all laboratories. This multicenter study involving a panel of European rules provides a framework for immunoblot interpretation that may be adapted according to the characteristics of Lyme borreliosis in local areas (http://www.eucalb.com).

In Europe, where the aim of testing is more clinically orientated, some authors have emphasized that the rules for interpretation must define a strain specifically. ${ }^{31}$ The ELISA and Western blot tests currently available in the USA are optimized for detection of B. burgdorferi sensu stricto. Sensitivity of these tests for the strains of B. burgdorferi sensu lato present in Europe and Asia (B. garinii and B. afzelii) is often limited. The variable major protein-like sequence $\mathrm{E}$ (VlsE) sixth invariant region (C6) epitope is relatively stable when comparing European and US species, so VlsE C6 ELISAs may be more appropriate for detecting all species of B. burgdorferi. ${ }^{30-36}$

Complete standardization of immunoblotting protocols in Europe is not possible at present. However, the development of immunoblots using defined recombinant or synthetic antigens is promising for the future..$^{24,32,35}$ The immunoblot assay is a significant innovation in comparison with the Western blot. The immunoblot includes only the antigens essential for the diagnosis, which are deposited in designated areas on the strips, greatly facilitating clarity of the test. The antigens used may also include those for differentiating Epstein-Barr virus or syphilis. There is no standardized panel of antigens composition for immunoblots due to the same disadvantages present at manufacturing ELISA and Western blot tests (eg, different genospecies). ${ }^{24,30}$

The other technologic innovation is the use of multiplex assays, in which the concentration of antibodies against single selected antigens is simultaneously evaluated by ELISA. The complex pattern of antigens, taken together with the timedependent dynamics of their expression during the course of the disease, requires more sophisticated methods to enable a more detailed overview of the generation of corresponding antibodies. The results can show reactions with many antigens in an assay simultaneously in one time point.

Serologic diagnosis in Europe and the USA relies on a two-step strategy. According to European Concerted Action on Lyme Borreliosis, Centers for Disease Control and Prevention, the first step consists of an ELISA screening with a specificity of at least $90 \%$ established in a healthy blood donor population. If positive or equivocal, a confirmatory test based on a blot assay providing a very high specificity must be performed (Figure 2). ${ }^{24}$ Despite these recommendations, serologic diagnosis of Lyme borreliosis remains challenging due to the complexity of the antigenic composition of the bacteria and the different temporal appearance of antibodies to different antigens. , $^{9,29,30,33}$

\section{Development of immune response}

IgM antibodies are detected first, and usually 3 weeks following initial infection. $\operatorname{IgM}$ antibodies persist for a long time and are often directed against the inner and outer parts of the flagella $(41 \mathrm{kDa})$, together with polyclonal activation of B lymphocytes. The isolated presence of IgM antibodies (using ELISA and blot techniques) should not be used as the basis for diagnosis of late Lyme disease, because levels can be sustained for many months, often giving a false-positive result. ${ }^{4}$ 
The IgG response occurs about 3-6 weeks after infection. ${ }^{4}$ IgG antibodies are accompanied by changes in the organ subject to time evolution, ie, over time they react with more antigens. However, they do not prevent reinfection. IgG antibodies may remain detectable for years after successful treatment and recovery from Lyme disease, and are more specific than IgM. Tests that do not differentiate antibody classes are not recommended, except for tests that use antigen C6. Due to early seroconversion class M and G antibody and its high specificity, it is a popular assay in the USA.

\section{Antigens in the diagnosis of Lyme disease}

Among the large group of immunogenic proteins generated by $B$. burgdorferi infection are antibodies that are common and nonspecific, and cause cross reactions with other spirochete bacteria, even ones that are unrelated. ${ }^{19,20}$ There are also important components of the solid protein with a molecular weight of $41 \mathrm{kDa}$ (flagellin p41) or HSP $60 \mathrm{kDa}$ (heat shock protein 60). Both groups of proteins are commonly found in nature and therefore often cross react with other bacteria. Other common antigens frequently observed include P66, P68, P71, and P73. It is essential that laboratory strains present a constant pattern of antigens. Some antigens undergoing immunology pressure in an infected host are replaced by others, and some undergo variability at the time of infection. Specific proteins are essential for diagnosis. Antibodies against specific antigens are the most valuable for diagnosis of Lyme borreliosis. The other group are specific proteins that are considered characteristic of $B$. burgdorferi genospecies, and include OspA (31 kDa), OspB (34 kDa), OspC (21-24 kDa), BmpA (P39), P93, P83/100, OspE (19 kDa), and OspF (26 kDa) (Table 2).

Knowledge of the properties of individual antigens and their appearance in infection is important when interpreting the results of Western blot or immunoblot tests (Table 2). To improve the specificity of the assays, antigens appearing during infection were introduced into testing. The antigens appearing during mammalian infection, so-called "in vivo" antigens, are particularly important. ${ }^{37}$

The spirochete undergoes changes in antigenic composition as it is transmitted between its arthropod and mammalian host, and this variation plays an important role in immune detection and destruction. Major proteins or lipoproteins known as variable major proteins (VMP or VMP-like sequence Vls) are responsible for this antigenic variation strategy, which has evolved to avoid immune detection and destruction. The protein that increases the quality of the test is VlsE C6, a superficial lipoprotein that is subject to antigenic variation. The highly heterogeneous VlsE protein contains conserved epitopes common to most genospecies. ${ }^{38-43}$

The amino acid sequence homology between the antigens shows considerable heterogeneity ( $40 \%-68 \%$ for OspC). The panel of combined recombinant antigens enables to present antigens, catching up antibodies against antigens from all genospecies. Using recombinant test systems, in which the most relevant antigens from several genospecies are combined on one strip, enable to offer in vivo expressed antigen in the sufficient amount. ${ }^{40,43}$

\section{False-negative results}

A negative serologic test result does not exclude the disease. In the early localized form of Lyme disease, most test results are negative. ${ }^{19,20,27}$ Successful antibiotic treatment of erythema migrans causes decreasing antigen presence and low production of antibodies are not detected. Thus, a negative result does not rule out early Lyme disease, because the serum sample may have been drawn before appearance of antibodies or may contain antibodies in quantities below the limits of the test used.

\section{False-positive results}

Cross-reactivity may cause false-positive results, leading to overdiagnosis of Lyme disease. In a healthy population, the false-positive rate is $8 \%-12 \% .{ }^{18}$ Cross reactivity may take place with other bacteria (Treponema pallidum and Treponema pertenue, as well as other nonpathogenic Borrelia and Leptospira) and during certain viral infections that invoke production of polyclonal antibodies, such as EpsteinBarr virus. A false-positive response may occur in certain autoimmune diseases (eg, rheumatoid arthritis, systemic lupus erythematosus) and in liver disease (eg, hepatitis C). The clinical problem is the proportion of positive results in clinically well subjects, as well as persistence of the antibody after treatment and resolution of symptoms. ${ }^{44-46}$

\section{Standards for diagnosis of Lyme disease}

Antibodies in the IgM class should be used in early Lyme disease and antibodies in IgG class should be used in late disease. Seroconversion of IgM antibodies to the IgG class is expected if the symptoms last for a few weeks. The diagnostic standard is a two-tier method involving use of a lower specificity and higher sensitivity assay, ie, ELISA or enzyme immunoassay, and then performing the test by means of Western blot, immunoblot, or multiplex. A two-step 
test approach using a sensitive enzyme immunoassay or an immunofluorescence antibody followed by Western blot is recommended. ${ }^{26}$

Although two-tier testing is standard practice in both the USA and Europe for serologic diagnosis of Lyme borreliosis, the test kits used are different. Wormser at al examined whether the tests used in the USA could detect Lyme borreliosis acquired in Europe and vice versa. ${ }^{7}$ Testing was performed using a convenience sample of archived serum samples from 40 patients with Lyme borreliosis from Austria and 39 from the USA, using first-tier and second-tier test kits from both the USA and Europe. The sensitivity of four first-tier tests from Europe and two first-tier tests from the USA was similar. Thus, two-tier testing was compared with the C6 ELISA as the first-tier test. The sensitivity of C6 two-tier testing with the US assays was $22.5 \%$ for detection of Lyme borreliosis acquired in Europe, and just 20.0\% in ten European patients with neurologic involvement. These results differed significantly from the sensitivity of European C6 two-tier testing, which was 70.0\% (95\% confidence interval 53.5-83.4) overall $(P<0.001)$ and 90.0\% $(95 \%$ confidence interval 55.5-99.7) for European patients with specific neurologic manifestations $(P=0.016)$. In contrast, the sensitivity of European and US two-tier C6 testing was similar for detection of Lyme borreliosis acquired in the USA. Two-tier serologic testing with the US test kits may be unsatisfactory for detection of Lyme borreliosis acquired in Europe. First-tier testing with an assay such as the C6 ELISA should be considered as a stand-alone diagnostic strategy in such cases. ${ }^{6}$ Diagnosis of Lyme disease, in addition to taking into account the considerable heterogeneity of B. burgdorferi strains, also creates other difficulties in interpretation.

\section{Antigen VIsE (C6)}

Tests linking antibody IgM and IgG (total) against the VlsE antigen (C6) that capture antibodies in the initial phase of the disease (IgM) during and after conversion to IgG are popular in the USA. Tests based on a conservative protein VlsE C6 group increase the likelihood of detection of antibodies, combining the ability to detect bacteria with high antigenic variation even within species. ${ }^{34-43}$

A single-step V1sE C6 ELISA (VlsE C6 peptide ELISA, or C6 test) measures IgG to VlsE C6. IgG antibodies to the C6 invariant region develop early (within the first week), giving it sensitivity comparable with that of IgM ELISA tests, but with improved specificity. ${ }^{13}$ A conditional two-tier strategy for serologic anti- $B$. burgdorferi antibody testing is recommended to support the diagnosis of Lyme disease in Europe. ${ }^{24,30}$

\section{Monitoring of antibodies after treatment}

Monitoring of serum antibodies after treatment is not considered to be reasonable unless reinfection is suspected. The inertia of antibody production cause memory $\mathrm{T}$ cells is high and does not accompany the elimination of bacteria. A common phenomenon is the persistence of IgM antibodies after successful treatment without seroconversion to $\mathrm{IgG} .{ }^{4}$ Monitoring is useful in endemic areas where reinfection is possible, and indicates appearance of new symptoms, the severity of symptoms, with a significant increase in antibodies.

\section{Diagnosis of neuroborreliosis}

It is difficult to determine antibodies confirming infection in the nervous system. The same restrictions with regard to interpretation of ELISA results in serum apply to cerebrospinal fluid. Furthermore, concentrations of antibodies in the two compartments, ie, blood and cerebrospinal fluid, are variable depending on compartmentalization (anatomic sequestration) and immunologic phenomena at immunologically privileged sites, such as the intrathecal space. ${ }^{47,48}$ Therefore, to confirm synthesis of antibodies in cerebrospinal fluid, antibodies should be measured in both serum and cerebrospinal fluid, and the results converted using a method that takes into account differences in protein levels between the two compartments. The result is expressed in the form of a so-called antibody index (AI): ${ }^{49-53}$

$$
\begin{aligned}
& \text { Index CSF/serum }[\mathrm{AI}] \\
& =\frac{\mathrm{CSF} \text { ELISA units } \times \text { total serum } \mathrm{IgG}}{\text { ELISA units in serum } \times \text { total } \mathrm{IgG} \text { in } \mathrm{CSF}}
\end{aligned}
$$

where CSF is the cerebrospinal fluid and a positive result is indicated by a value $>2.0$.

Detection of intrathecally produced specific antibodies (AI) is essential for the diagnosis of Lyme neuroborreliosis; however, the performance of various newer AI detection methods has not been systematically assessed. Stanek et al assessed and compared three advanced antibody systems for detecting borrelia IgG AI and IgM AI, ie, chemiluminescence and two ELISAs using different antigens for detection of IgG and IgM antibodies. IgG AI and IgM AI were not detected within the first week of infection. Duration of the disease correlated with IgG AI, but IgM AI results were heterogeneous for each assay tested. Moreover, levels 
of IgG AI but not IgM AI were correlated with the protein concentration in cerebrospinal fluid. The highest sensitivity and specificity was achieved by the antibody detection assay using VlsE IR6 peptide. Detection of IgM AI yielded heterogenous results and did not support a laboratory diagnosis of neuroborreliosis. ${ }^{40}$

Henningsson et al compared the performance of a second-generation Lyme neuroborreliosis test (from Oxoid, Basingstoke, UK) based on a purified native flagellum antigen with that of two newly developed tests based on several recombinant antigens for diagnosis of neuroborreliosis. The first test had an overall sensitivity (IgM and IgG AIs taken together) of $88 \%$ and a specificity of $99 \%$. The second test had a sensitivity of $86 \%$ and a specificity of $97 \%$. An overall sensitivity of $100 \%$ and a specificity of $97 \%$ were achieved by the third test. ${ }^{47}$

An alternative method, indicating intrathecal synthesis, reveals the presence of antibodies simultaneously in cerebrospinal fluid and serum by means of Western blot or immunoblot and compares them. A Western blot or immunoblot test constructed identically for serum and cerebrospinal fluid enables detection of antibodies against particular antigens, making the results of ELISA more objective. Moreover, this test detects the presence of oligoclonal bands. The presence of strongly stained bands in cerebrospinal fluid and their absence in serum indicates intrathecal synthesis.

\section{Direct tests in Lyme borreliosis}

Polymerase chain reaction (amplification of bacterial DNA), cultivating B. burgdorferi bacteria taken from cerebrospinal fluid, or visualizing their presence in tissues (like skin biopsy) belongs to direct tests enabling direct detection of an infectious agent. Enhanced detection of host response antibodies to $B$. burgdorferi using immuno-polymerase chain reaction is very promising. Immuno-polymerase chain reaction (iPCR) combines amplification power of PCR with traditional immunoassay. Electron microscopy can be particularly useful in the detection of bacterial cells. Direct animal tests and polymerase chain reaction, apart from their numerous limitations and high costs, are time-consuming and therefore not useful for standard clinical diagnostics. Polymerase chain reaction is recommended only in selected situations and should be used in combination with serology to support the diagnosis. ${ }^{53-56}$

\section{Summary}

There are many tests for Lyme disease based on antibody detection. Despite the presence of new and improved assays, laboratory diagnosis of Lyme disease remains a research topic. The variety of genospecies and their different geographic distributions are the reasons why standards and recommendations are not the same for all the main geographic regions, ie, the USA, Asia, and Europe. Moreover, the variety and variability of antigens is still a challenge in composition of a standard set of antigens (and use standard units of antibodies concentration). Further studies should focus on detecting the lowest concentration of antibodies and looking for useful new antigens, and the relationship between composition of such antigens and the patient's clinical status.

\section{Disclosure}

The authors report no conflicts of interest in this work.

\section{References}

1. Steere AC, Coburn J, Glickstein L. The emergence of Lyme disease. Clin Invest. 2004;113(8):1093-1101.

2. Stanek G, Reiter M. The expanding Lyme Borrelia complex - clinical significance of genomic species? Clin Microbiol Infect. 2011;17(4): 487-493.

3. Stanek G, Fingerle V, Hunfeld KP, et al. Lyme borreliosis: clinical case definitions for diagnosis and management in Europe. Clin Microbiol Infect. 2011;17(1):69-79.

4. Halperin JJ, Baker P, Wormser GP. Common misconceptions about Lyme disease. Am J Med. 2013;126(3):264. e1-e7.

5. Weinstein A. Editorial commentary: laboratory testing for Lyme disease: time for a change? Clin Infect Dis. 2008;47(2):196-197.

6. Zajkowska J, Lewczuk P, Strle F, et al. Lyme borreliosis: from pathogenesis to diagnosis and treatment. Clin Dev Immunol. 2012;2012: 231657.

7. Wormser GP, Tang AT, Schimmoeller NR, et al. Utility of serodiagnostics designed for use in the United States for detection of Lyme borreliosis acquired in Europe and vice versa. Med Microbiol Immunol. 2014;203(1):65-71.

8. Aguero-Rosenfeld ME, Wang G, Schwartz I, et al. Diagnosis of Lyme borreliosis. Clin Microbiol Rev. 2005;18(3):484-509.

9. Wang G, Aguero-Rosenfeld M, Wormser GP, et al. Detection of Borrelia burgdorferi. In: Samuels DS, Radolf JD, editors. Borrelia: Molecular Biology, Host Interaction, and Pathogenesis. Norfolk, UK: Caister Academic Press; 2010.

10. Aguero-Rosenfeld ME. Lyme disease: laboratory issues. Infect Dis Clin North Am. 2008;22(2):301-313.

11. Tugwell P, Dennis DT, Weinstein A, et al. Laboratory evaluation in the diagnosis of Lyme disease. Ann Intern Med. 1997;127(12): 1109-1123.

12. Craven RB, Quan TJ, Bailey RE, et al. Improved serodiagnostic testing for Lyme disease: results of a multicenter serologic evaluation. Emerg Infect Dis. 1996;2(2):136-140.

13. Steere AC, McHugh G, Damle N, Sikand VK. Prospective study of serologic tests for Lyme disease. Clin Infect Dis. 2008;47(2): 188-195.

14. Brown SL, Hansen SL, Langone JJ. Role of serology in the diagnosis of Lyme disease. JAMA. 1999;282(1):62-66.

15. Kaiser R, Rauer S. Advantage of recombinant borrelial proteins for serodiagnosis of neuroborreliosis. J Med Microbiol. 1999;48(1): 5-10.

16. Kaiser R, Rauer S. Analysis of the intrathecal immune response in neuroborreliosis to a sonicate antigen and three recombinant antigens of Borrelia burgdorferi sensu stricto. Eur J Clin Microbiol Infect Dis. 1998;17(3):159-166.

17. Gajović O, Todorović Z, Nesić L, Lazić Z. [Lyme borreliosis - diagnostic difficulties in interpreting serological results]. Med Pregl. 2010;63(11-12):839-843. Serbian. 
18. Chmielewski T, Tylewska-Wierzbanowska S. Występowanie przeciwciał swoistych dla B. burgdorferi u ludzi zdrowych na terenie [Prevalence of Borrelia burgdorferi antibodies in healthy population in Poland]. Przegl Epidemiol. 2002;56(1):33-38. Polish.

19. Wilske B. Diagnosis of Lyme borreliosis in Europe. Vector Borne Zoonotic Dis. 2003;3(4):215-227.

20. Wilske B, Fingerle V, Schulte-Spechtel U. Microbiological and serological diagnosis of Lyme borreliosis. FEMS Immunol Med Microbiol. 2007;49(1):13-21.

21. Kalish RA, McHugh G, Granquist J, Shea B, Ruthazer R, Steere AC. Persistence of immunoglobulin $\mathrm{M}$ or immunoglobulin $\mathrm{G}$ antibody responses to Borrelia burgdorferi 10-20 years after active Lyme disease. Clin Infect Dis. 2001;33(36):780-785.

22. Feder HM Jr, Gerber MA, Luger S, Ryan RW. Persistence of serum antibodies to Borrelia burgdorferi in patients treated for Lyme disease. Clin Infect Dis. 1992;15(5):788-793.

23. Gordis L. Assessing the validity and reliability of diagnostic and screening tests. In: Epidemiology. 2nd ed. Philadelphia, PA, USA: WB Saunders; 2000.

24. European Concerted Action On Lyme Borreliosis. Available from: http:// www.eucalb.com/. Accessed April 4, 2014.

25. [No authors listed]. Guidelines for laboratory evaluation in the diagnosis of Lyme disease. American College of Physicians. Ann Intern Med. 1997;127(12):1106-1108.

26. Centers for Disease Control and Prevention. Recommendations for test performance and interpretation from the Second National Conference on Serologic Diagnosis of Lyme Disease. MMWR Morb Mortal Wkly Rep. 1995;44(31):590-591.

27. Goettner G, Schulte-Spechtel U, Hillermann R, Liegl G, Wilske B, Fingerle V. Improvement of Lyme borreliosis serodiagnosis by a newly developed recombinant immunoglobulin $\mathrm{G}(\mathrm{IgG})$ and $\operatorname{IgM}$ line immunoblot assay and addition of VlsE and DbpA homologues. J Clin Microbiol. 2005;43(8):3602-3609.

28. Dressler F, Whalen JA, Reinhardt BN, Steere AC. Western blotting in the serodiagnosis of Lyme disease. J Infect Dis. 1993; 167(2):392-400.

29. Nowakowski J, Schwartz I, Liveris D, et al. Laboratory diagnostic techniques for patients with early Lyme disease associated with erythema migrans: a comparison of different techniques. Clin Infect Dis. 2001;33(12):2023-2027.

30. Aguero-Rosenfeld ME, Nowakowski J, Bittker S, Cooper D, Nadelman RB, Wormser GP. Evolution of the serologic response to Borrelia burgdorferi in treated patients with culture-confirmed erythema migrans. J Clin Microbiol. 1996;34(1):1-9.

31. Hunfeld KP, Kraiczy P. When to order a Western blot and how to interpret it. Curr Probl Dermatol. 2009;37:169-177.

32. Steere AC, McHugh G, Damle N, Sikand VK. Prospective study of serologic tests for Lyme disease. Clin Infect Dis. 2008;47(2):188-195.

33. Hunfeld KP, Stanek G, Straube E, et al. Quality of Lyme disease serology. Lessons from the German Proficiency Testing Program 1999-2001. A preliminary report. Wien Klin Wochenschr. 2002; 31(13-14):591-600.

34. Ledue TB, Collins MF, Young J, Schriefer ME. Evaluation of the recombinant VlsE-based liaison chemiluminescence immunoassay for detection of Borrelia burgdorferi and diagnosis of Lyme disease. Clin Vaccine Immunol. 2008;15(12):1796-1804.

35. Zajkowska JM, Kondrusik M, Pancewicz SA, et al. [Comparison of test with antigen VlsE (C6) with tests with recombinant antigens in patients with Lyme borreliosis]. Pol Merkur Lekarski. 2007;23(134):95-99. Polish.

36. Peltomaa M, McHugh G, Steere AC. Persistence of the antibody response to the VlsE sixth invariant region (IR6) peptide of Borrelia burgdorferi after successful antibiotic treatment of Lyme disease. J Infect Dis. 2003;187(8):1178-1186.
37. Zajkowska J, Kondrusik M, Grygorczuk S, et al. The usefulness of 'in vivo' antigens in the diagnosis of human Lyme borreliosis. Int $J$ Med Microbiol. 2008;298 Suppl 1:361-364.

38. Bacon RM, Biggerstaff BJ, Schriefer ME, et al. Serodiagnosis of Lyme disease by kinetic enzyme-linked immunosorbent assay using recombinant VlsE1 or peptide antigens of Borrelia burgdorferi compared with 2-tiered testing using whole-cell lysates. J Infect Dis. 2003;187(8):1187-1199.

39. Branda JA, Aguero-Rosenfeld ME, Ferraro MJ, Johnson BJ, Wormser GP, Steere AC. 2-tiered antibody testing for early and late Lyme disease using only an immunoglobulin $\mathrm{G}$ blot with the addition of a VlsE band as the second-tier test. Clin Infect Dis. 2010;50(1):20-26.

40. Stanek G, Lusa L, Ogrinc K, Markowicz M, Strle F. Intrathecally produced IgG and IgM antibodies to recombinant VlsE, VlsE peptide, recombinant OspC and whole cell extracts in the diagnosis of Lyme, neuroborreliosis. Med Microbiol Immunol. 2014;203(2):125-132.

41. Zajkowska J, Kondrusik M, Grygorczuk S, et al. Comparison of two types of diagnostic test detecting antibodies against Borrelia burgdorferi: EIA based on one genospecies antigens and ELISA based on recombinant antigens. Przeg Epidemiol. 2006;60 Suppl 1:171-176.

42. Zajkowska J, Kondrusik M, Pancewicz S, et al. Western-blot with VlsE protein and "in vivo" antigens in Lyme borreliosis diagnosis. Przegl Epidemiol. 2006;60 Suppl 1:177-185.

43. Sillanpää H, Lahdenne $P$, Sarvas $H$, et al. Immune responses to borrelial VlsE IR6 peptide variants. Int J Med Microbiol. 2007;297(1):45-52.

44. Luft BJ, Dunn JJ, Dattwyler RJ, Gorgone G, Gorevic PD, Schubach WH. Cross-reactive antigenic domains of the flagellin protein of Borrelia burgdorferi. Res Microbiol. 1993;144(4):251-257.

45. Magnarelli LA, Miller JN, Anderson JF, Riviere GF. Cross-reactivity of nonspecific treponemal antibody in serologic tests for Lyme disease. $J$ Clin Microbiol. 1990;28(6):1276-1279.

46. Magnarelli LA, Anderson JF. Enzyme-linked immunosorbent assays for the detection of class-specific immunoglobulins to Borrelia burgdorferi. Am J Epidemiol. 1988;127(4):818-825.

47. Henningsson AJ, Christiansson M, Tjernberg I, Löfgren S, Matussek A. Laboratory diagnosis of Lyme neuroborreliosis: a comparison of three CSF anti-Borrelia antibody assays. Eur J Clin Microbiol Infect Dis. November 22, 2013. [Epub ahead of print.]

48. Hansen K, Lebech AM. Lyme neuroborreliosis: a new sensitive diagnostic assay for intrathecal synthesis of Borrelia burgdorferi-specific immunoglobulin G, A, and M. Ann Neurol. 1991;30(2):197-205.

49. Reiber H, Peter JB. Cerebrospinal fluid analysis: disease-related data patterns and evaluation programs. J Neurol Sci. 2001;184(2):101-122.

50. Mygland A, Ljostad U, Fingerle V, et al. EFNS guidelines on the diagnosis and management of European Lyme neuroborreliosis. Eur J Neurol. 2010;17(1):8-16.

51. Blanc F, Jaulhac B, Fleury M, et al. Relevance of the antibody index to diagnose Lyme neuroborreliosis among seropositive patients. Neurology. 2007;69(10):953-958.

52. Hammers-Berggren S, Hansen K, Lebech AM, et al. Borrelia burgdorferi-specific intrathecal antibody production in neuroborreliosis: a follow-up study. Neurology. 1993;43(1):169-175.

53. Ljøstad U, Skarpaas T, Mygland A. Clinical usefulness of intrathecal antibody testing in acute Lyme neuroborreliosis. Eur J Neurol. 2007; 14(8):873-876.

54. Cerar T, Ogrinc K, Cimperman J, Lotric-Furlan S, Strle F, RuzićSabljić E. Validation of cultivation and PCR methods for diagnosis of Lyme neuroborreliosis. J Clin Microbiol. 2008;46(10):3375-3379.

55. Dunaj J, Moniuszko A, Zajkowska J, Pancewicz S. The role of PCR in diagnostics of Lyme borreliosis. Przegl Epidemiol. 2013;67(1):35-39, 119-123.

56. Lebech AM, Hansen K, Brandrup F, Clemmensen O, Halkier-Sørensen L. Diagnostic value of PCR for detection of Borrelia burgdorferi DNA in clinical specimens from patients with erythema migrans and Lyme neuroborreliosis. Mol Diagn. 2000;5(2):139-150. 
Antibody Technology Journal

Dovepress

\section{Publish your work in this journal}

Antibody Technology Journal is international, peer-reviewed, open access journal publishing original research, reports, reviews and commentaries on all areas of antibody technology. The manuscript management system is completely online and includes a very quick and fair

peer-review system. Visit http://www.dovepress.com/testimonials.php to read real quotes from published authors. 